\title{
ARCHITECTURE UTOPIA REALISM: THEMATIC FRAMEWORK
}

\author{
A B S T R A C T
}

The term or concept of realism seems to be recurring in recent theoretical inquiries, from debates in philosophy and aesthetics to those in theory and practice of architecture. Since 2000, the architectural discourse has been concerned with a wide range of related issues coming from its own post-critical debates on utopianism and realism and the possibility of an 'utopian realism', as suggested by Reinhold Martin (2005). The debates on realism resonate in the architectural theory anew as a reflection on the Manifesto of New Realism by the philosopher Maurizio Ferraris from 2011. The questions of realism vs. postmodernism, "new realism" on the ashes of post-modernism, critical and operative notions of realism and the like, have been asked both through practices of contemporary architecture and through reconsideration of the socialist realism in history and theory of architecture. The thematic issue of SAJ: Architecture Utopia Realism aims to further the ongoing discussion on the relations of architecture with realism and utopia. 


\section{INTRODUCTION}

This thematic issue of Serbian Architecture Journal is a follow-up to the International Scientific Conference: Architecture Utopia Realism (AUR), organized by the University of Belgrade - Faculty of Architecture, on $3^{\text {rd }}$ and $4^{\text {th }}$ October 2013. ${ }^{1}$ The conference was accompanied by the exhibition "Ivan Leonidov: Projects", which was organized and produced in partnership between the Schusev State Museum of Architecture in Moscow and the Faculty of Architecture in Belgrade. ${ }^{2}$ The conference theme extended as an underlying topic of the AUR Guest Lectures Program organized by the Belgrade Faculty of Architecture during the academic year 2013-2014. ${ }^{3}$ The inquiry into realism in architecture as the main topic of the international conference was first suggested by the philosopher Petar Bojanić who contributed important theoretical and terminological clarifications in the conference opening speech. In the conference call for papers, speakers were invited to reflect on multivalent relations of practices and theory of avant-garde, modern and contemporary architecture to concepts and issues, such as utopianism, realism, social realism, socialist realism, neo-realism, utopian realism, new realism and the like. ${ }^{4}$ The topics followed after and extended those addressed in a series of conferences titled Architecture and Realism and organized by the Italian colleagues in Turin, Naples and Milan in 2012. ${ }^{5}$ Silvia Malcovati of the Polytechnic of Turin, as the member of the scientific and organizing committees of the Italian events, opened the first session of the AUR conference. In her presentation, she pointed to Italian discussions on the subject and focused on the varied perspectives of realisms in the $20^{\text {th }}$ century in relation to the notion of "new realism", introduced by the Italian philosopher Maurizio Ferraris. Her article in this journal, "The Utopia of Reality. Realisms in Architecture between Ideology and Phenomenology", gives a comprehensive and well documented reading which interprets the debates which have taken place in Italy and elsewhere since the 1950s.

\section{MULTIPLE READINGS OF REALISM \\ IN ARCHITECTURAL DISCOURSE}

The editorial framework of the Architecture Utopia Realism thematic issue of this journal reflects anew, that is, from the historical distance of some thirty five years, some of the issues laid out by Bernard Huet in his editorial to the thematic issue of the journal L'Architecture D'Aujourd'hui (AA): FormalismeRéalisme. The subtitles of the Huet's editorial from 1977 seemed to me to be an appropriate point of departure for re-consideration of a range of issues, from the "Tribute to Socialist Realism", "Avatars of Realism" and "From Neo- 
Realism to la Tendenza" to "Extending the Notions of Realism and Formalism". Huet's argument is open and it concludes by implying a plurality of readings, saying that there is not one form of realism, since realism is as multiple as the reality that it reflects. ${ }^{6}$ How can such plurality of interpretations from varied points of view, critical, theoretical, historical and design practice related, be examined today? Indeed, as we shall read in Alessandro de Magistris's article in this issue of $S A J$, a close re-reading of the Soviet experience in the 1930s opens a view into the varied outcomes and meanings of realism or, rather, socialist realism in the practice of architecture and urbanism. The article demonstrates a complexity of socialist realism as a process and opposes its simplified interpretation as a dogma. It argues against exclusion of soc-realism from the dominant narratives of contemporary architecture and its proper reevaluation as a practice of architecture. On the other hand, the contradictory aspects of utopianism and realism in modern art and architecture, as well as multiple manifestations and interpretations of these notions are addressed by Luka Skansi in his article "Manfredo Tafuri and the Critique of Realism".

To return to critical perspectives of thirty five years ago and Martin Steinmann's and Bruno Reichlin's contribution to the same issue of $A A$ titled "Concerning Immanent Reality". I would argue that this article provides an interpretation of realism that can well be suited to our own time. Rather than playing out the rehearsed opposition of realism $v s$. formalism, the article proposes the relation of realism and autonomy which is based on Roman Jakobson's thesis on realism in literature from 1921. Reichlin and Steinmann summarize Jakobson's thesis and say that: "the bases of realism in literature were to be found in social developments, whereas the processes which give form to these from an aesthetic point of view only have meaning when seen within the literary structure themselves". 7 Thus, Steinmann and Reichlin speak about "levels of reality intrinsic to architecture alone", in other words, they say "architecture does not reflect only a social reality, but has its own proper reality, which is its formal quality". ${ }^{8}$ Such an interpretation of architecture's own proper reality or its autonomy is where realism and utopia might be seen as coming in close proximity. Thus the journal invites responses by contemporary design practice, as the one contributed here by Krunoslav Ivanišin who discusses notions of real and reality in relation to the notions of place and, inversely, non-place.

In the late 1970s, the projects and drawings published alongside theoretical debates and essays in the aforementioned issue of $A A$ clearly belonged to the postmodernist iconography of the period. There is little reality in the reproduced imagery, such as in Massimo Scolari's cover piece or the drawings 
reproduced as illustrations to his article "The Utopia of Reality", which depict architectural flights of fancy, titled accordingly Les résurgences et le naufrage (1974), L'ange exterminateur (1976) or Le songe de l'argonaute (1976) and the like. ${ }^{9}$ This postmodern realism, if I may call it that way, is a sort of bricolage realism, which reworks or, rather, tinkers with the reusable trans-historical material, be it oneiric, romantic, fantasy or objectivist. Distinct from the hitherto prevalent practice-led discourse, the nascent architectural discourse of postmodernism detached itself from the social realities of economy, construction, technology and production and transferred itself into the fields of art and culture. ${ }^{10}$ Even though mainstream postmodernism in the so called First World has been well researched and critically re-considered, there is still much to learn about the parallel processes which took place on the other side of the real and imaginary curtain, that is in the lands of real-socialism. There, I wonder if bricolage material comes from the repository of the largely dismantled repertoire of the socialist realism. While in the socialist $1980 \mathrm{~s}$, the postmodernist imagination re-used material of the avant-garde utopianism, the post-socialist 1990s introduced socialist-realist motives in the critique of the exhausted and ideologically discharged demise of socialism following the Fall of the Wall. The art project "Yugomuzej" (1999), by the Belgrade sculptor Mrđan Bajić, is an illustrative example; the artist superimposes huge hammer and sickle element over IBM logo on top of an imaginary structure representing the museum of paradoxes from the socialist-realist history of the no longer existing country of Yugoslavia. (Figure 1)

Fredric Jameson pointed to the relations of realism and postmodernism in his Wellek Library Lectures in Critical Theory given at the University of California, Irvine, in 1991. In the semiotic square he constructs in the lecture titled "The Constraints of Postmodernism", the term/notion realism, that is

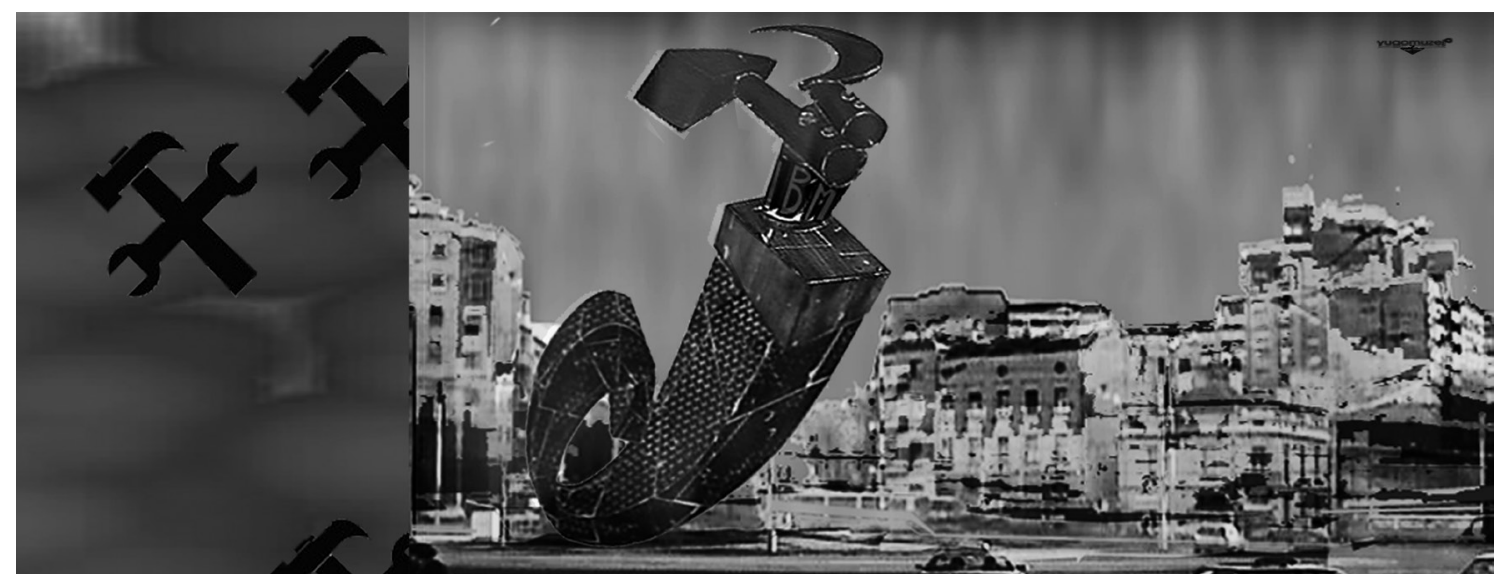

Figure 1. Mrđan Bajić, Yugomuzej, 1999, lambda print. Courtesy of the artist. 
"dirty realism" to be precise, finds itself opposite "deconstructionism", while "high modernism" is opposed to "stylistic postmodernism". ${ }^{11}$ Jameson finds the very intent to apply a term such as realism to architecture to be problematic, and explains: "If by realism we mean mimesis of some sort, then it is certainly not clear from the outset how any architecture could be considered realistic". ${ }^{12}$ He looks at architecture's realism from his own disciplinary ground in literary criticism with reference to Liane Lefaivre's original reading of the term "dirty realism" as it applies in architecture. Lefaivre found the term in the special issue of the literary publication Granta with the thematic Dirty Realism: New Writing from America, in which the editor Bill Bufford promotes realism of "nonurban" that is "neoregionalist" writers. ${ }^{13}$ Jameson finds architecture's potential of mimesis in Venturi-Rauch-Brown line of realism or, as he terms it, the architecture "speaking the vernacular", yet argues that it also represents another form of postmodernism, such as ideology of regionalism or even critical regionalism:

Neoregionalism, like the neo-ethnic, is a specifically post-modern form of reterritorialization; it is a flight from the realities of late capitalism, a compensatory ideology, in a situation in which regions (like ethnic groups) have been fundamentally wiped out - reduced, standardized, commodified, atomized, or rationalized. The ideology of regionalism is the sentimentalization .... of the nature of the social life and the socioeconomic system $\ldots{ }^{14}$

In her article "Frank Lloyd Wright, Ayn Rand, and Hyper-Capitalist Utopia", Tijana Vujošević takes a close look into one such reterritorialisation. She looks at American anti urban planning ideal, that is, the agrarian utopia proposed in Wright's book The Disappearing City (1932) and engages in its comparative reading with the Rand's bestselling book The Fountainhead (1943).

Against rear-visions of utopianism/realism seen through the rear-mirror of neo-regional/ethnic/agrarian sentimentalization, Jameson suggests a hyper urban, hyper total space as a more promising starting point in the pursuit of a definition of dirty realism. Hyper urban, exemplified by Liane Lefaivre through the cyberpunk space of the Blade Runner (1982) movie provides a better springboard to think reality, as Jameson claims, not least because it is urban but because of a new reality-intensification, in which "the visionary exploration of cyberpunk and so-called dirty realism provisionally occupies the place that may eventually be occupied by a full dress theory of what follows civil society" (italic ours). ${ }^{15}$ In her lecture at the AUR Conference, Keller Easterling gave a chilling vision of the spatial consequences at the end of the 
civic and of processes that she calls "Extrastatecraft". ${ }^{16}$ I would suggest that the global "spatial product" she talked about relates to what Jameson described as "dirty realism as a collective built space". ${ }^{17}$ Spatially imagined as no-man'sland, writes Jameson, it is the space at „the end of the civic, for example, and of official government ... a space where neither private property nor public law exist", a zone perhaps, "a space beyond national or political jurisdiction". ${ }^{18}$ Against the proposition of dirty realism's collective space, New Realism, as philosophers would argue, opens a view to a new space of co-operation.

\section{CONCLUDING NOTE}

In his speech at the opening of the AUR conference, the philosopher Petar Bojanic proposed that New Realism stands for co-operation and that it is "the condition of a new European thought". Basing his argument on the rereading the 1912 book The New Realism: Cooperative Studies in Philosophy by six U.S. based philosophy scholars, he stressed that New Realism carries a "promise of completeness", that it is not an accident nor a tour de force, but a constructive philosophy and rejection of all mystical philosophy. Realism destroys all mysticism, says Bojanić, adding an important note that utopia is not mystic and utopianism is not mysticism. ${ }^{19}$ This statement adds a significant political shift to historiographical and theoretical study of realism in art and architecture and opens a perspective to operative and co-operative practice and, especially, co-operative practice of architecture.

The SAJ - AUR thematic issue, thus, aims to look at operative notion of realism in architecture, not as an operative criticism famously and effectively dismissed by Manfredo Tafuri, but as architectural operation of realism in practice and criticism.

NOTES
The conference gathered thirteen speakers from eight countries [Australia (1), Croatia (1), Germany (1), Italy (3), Russia (1), Serbia (3), UK (1) and USA (2)]. Videos of opening addresses and all lectures are available online, at: http://media.amres.ac.rs/multimedia/viewcategory/99/ international-scientific-conference-qarchitecture-utopia-realismq.html. Accessed 23rd May 2014 The initiative for collaboration between the two institutions came from Dr. Irina Korobina, Director of the Schusev State Museum of Architecture in Moscow, who opened the exhibition and gave her lecture presentation in the Gallery of the Faculty of Architecture in Belgrade on 3rd October 2013. For more information on the scientific committee, participants, conference program and exhibition, see: Petar Bojanić, Ljiljana Blagojević and Vladan Đokić, eds. A.U.R. - Architecture Utopia Realism. (Belgrade: University of Belgrade - Faculty of Architecture, 2013). Online information: http://www.arh.bg.ac.rs/2013/09/28/architecture-utopia-realisminternational-scientific-conference-exhibition/. Accessed 23rd May 2014

AUR Guest Lectures Program invited the following lecturers: Johan Bettum, professor, program director and interim dean at Städelschule Architecture Class, Frankfurt, Germany. Founder of ArchiGlobe, Frankfurt; Aristide Antonas, architect and writer, associate professor, University of Thessaly, Department of Architecture, Greece. Founder of Antonas Office, Athens; Ezio Manzini, 
professor of industrial design, Polytechnic, Milan, Italy. Director of the Interdepartmental Centre for Research on Innovation for Sustainability, Polytechnic, Milan; Matias Echanove, writer and activist, co-director of the Institute of Urbanology, Mumbai and Goa, India. Member of the URBZ.net collective; Tom van Malderen, architect and CEO of Architecture Project, Malta \& Chris Briffa, Founder of Chris Briffa Architects, Valetta, Malta; Anne Lacaton, founder and partner of Lacaton \& Vassal Architects, Paris, France. Visiting professor at EPF Lausanne, Harvard GSD, ETSA Madrid, etc; Emil Jurcan, architect, member of Pulska grupa, Pula, Croatia. Co-founder of Praksa collective; and Christina Diaz Moreno \& Efrén Garcia, associate professors of Architecture at ETSAM, Madrid and ESAYA, Madrid, Spain. Founders and partners of Amid.cero9, Madrid.

See: http://www.arh.bg.ac.rs/2013/10/25/architecture-utopia-realism-guest-lectureprogram-201314/. Accessed $27^{\text {th }}$ April 2014

Ljiljana Blagojević, “Architecture Utopia Realism," in: Architecture Utopia Realism, eds. Petar Bojanić, Ljiljana Blagojević and Vladan Đokić, (Belgrade: University of Belgrade - Faculty of Architecture, 2013) pp.14-15.

http://labont.it/wordpress/wp-content/uploads/2012/10/Turin_Naples_program.pdf

Bernard Huet, "Formalisme-Réalisme," L'Architecture d'aujourd'hui, 190 (1977): 35-36, quote p. English summary, p. 101

Martin Steinmann and Bruno Reichlin, “A-propo de la réalité immanente," L'Architecture d'aujourd'hui, 190 (1977): 72-73, quote p. English summary, p. 103

Ibid.

Massimo Scolari, “L'Utopie de la Réalité,” L'Architecture d'aujourd'hui, 190 (1977): 88-93.

Cf. Ljiljana Blagojević, "Postmodernism in Belgrade Architecture: Between Cultural Modernity and Societal Modernisation,” Spatium International Review, no. 25 (2011), 23-29.

Fredric Jameson, The Seeds of Time (New York: Columbia University Press, 1994), p. 133

Jameson, The Seeds of Time, p. 146

Bill Buford, "Editorial”, Granta, 8 (1983): 4-5

Jameson, The Seeds of Time, p. 146, 148

Ibid., p. 155.

Keller Easterling, "Extrastatecraft", key note lecture at AUR conference in Belgrade, available online: https://www.youtube.com/watch?v=r0vpcJnqy4U. Acessed 10th June 2014

Jameson, The Seeds of Time, p. 155

Ibid., pp. 158-159

Cf. Petar Bojanić, opening speech "The New Realism" at the AUR conference ( $3^{\text {rd }}$ October 2013), available online: http://media.amres.ac.rs/multimedia/viewvideo/500/internationalscientific-conference-qarchitecture-utopia-realismq/petar-bojani-conference-opening.html. Accessed 23rd May 2014 
Blagojević, Ljiljana. "Postmodernism in Belgrade Architecture: Between Cultural Modernity and Societal Modernisation. "Spatium International Review, 25 (2011): 23-29.

Bojanić, Petar; Ljiljana Blagojević and Vladan Đokić, eds. A.U.R. - Architecture Utopia Realism. International Scientific Conference, 3rd-4th October 2013. Book of Abstracts / Exhibition Catalogue. Belgrade: University of Belgrade - Faculty of Architecture, 2013

Buford, Bill. "Editorial." Granta, 8 (1983): 4-5

Huet, Bernard. "Formalisme-Réalisme," L'Architecture d'aujourd'hui, 190 (1977): 35-36.

Jameson, Fredric. The Seeds of Time. New York: Columbia University Press, 1994.

Scolari, Massimo. “L’Utopie de la Réalité.” L'Architecture d'aujourd'hui, 190 (1977): 88-93.

Steinmann, Martin and Bruno Reichlin. “A-propo de la réalité immanente.” L'Architecture d'aujourd'hui, 190 (1977): 72-73. 


\section{ARHITEKTURA UTOPIJA REALIZAM: TEMATSKI OKVIR Ljiljana Blagojević}

Termin ili koncept realizma re-aktuelizovan je u skorašnjim teorijskim debatama od rasprava u filozifiji i estetici do onih u teoriji i praksi arhitekture. Počev od 2000. godine, arhitektonski diskurs se često bavi širokim spektrom srodnih pitanja koja proističu iz post-kritičkih rasprava o utopijanizmu i realizmu i mogućnosti jednog "utopijskog realizma", kako je to sugerirao Rajnhold Martin (2005). Rasprave o realizmu ponovo rezoniraju u arhitektonskoj teoriji kao odraz Manifesta novog realizma, filozofa Mauricija Ferarisa iz 2011 godine. Pitanja realizma naspram postmodernizma, "novog realizma" koji nastaje na pepelu post-modernizma, kritički i operativni pojmovi realizma i slično, postavljana su kako kroz prakse savremene arhitekture tako i kroz preispitivanje realizma i socijalističkog realizma u istoriji i teoriji arhitekture. Postavka tematskog okvira u ovom članku SAJ: Arhitektura Utopija Realizam ima za cilj da produbi tekuće rasprave o odnosima arhitekture sa realizmom i utopijom.

KLJUČNE REČI: ARHITEKTURA, UTOPIJA, REALIZAM, AUR MEĐUNARODNA NAUČNA KONFERENCIJA, UNIVERZITET U BEOGRADU - ARHITEKTONSKI FAKULTET

\section{UTOPIJA STVARNOSTI. REALIZMI U ARHITEKTURI IZMEĐU IDEOLOGIJE I FENOMENOLOGIJE Silvia Malcovati}

Predložen povodom Prvog Kongresa sovjetskih pisaca u Moskvi 1934 godine, pojam realizma u teorijskim raspravama o arhitekturi u ranim tridestim godinama dvadesetog veka, izgleda kao dvosmisleni pojam, koji se koleba između idealizma i ideologije, inovativnog istraživanja i istoricističkog formalizma. Neuspeh socijalističkog realizma i kriza njegove naglašene i monumenalističke arhitektonske slike, jasno pokazuju utopijski karakter realističkog "sna", ali isto tako, na neki način, njegovu maštovitu moć nastojanja da se izgradi bolji svet.

Pitanje realizma aktuelno je i posle Drugog svetskog rata. Posebno u Italiji realizmi se pretvaraju u alternative savremenoj paradigmi, ni manje ni više utopijski, već otvoreni prema novim postmodernističkim američkim idejama, kao i arhitekturi grupe "Tendenza".

U ovom radu predloženo je pregledno istraživanje realizama dvadesetog veka kao instrumenta koji odražava stanje u arhitekturi: nakon ekscesa postmodernog populizma, razočarenja "Architettura Razionale" i dijalektike rekonstrukcije - dekonstrukcije, izgleda da se ponovo pojavljuje u arhitekturi jedan novi bauk "Realizma" kao način reagovanja na trenutno arhitektonsko i urbano stanje.

KLJUČNE REČI: UTOPIJA, REALIZAM, ITALIJANSKA ARHITEKTURA POSLERATNOG PERIODA, “TENDENZA”, POSTMODERNIZAM, NOVI REALIZAM, ARHITEKTURA GRADA

\section{(SOC)REALIZMI U PRAKSI: PONOVNO ČITANJE SOVJETSKOG ISKUSTVA IZ TRIDESTIH GODINA PROŠLOG VEKA \\ Alessandro De Magistris}

Diskurs o realizmu u savremenoj arhitektonskoj raspravi izgleda da zaobilazi složenost istorijskih korena ove pojave u arhitekturi dvadesetog veka i, posebno, diskurs o socijalsitičkom realizmu: izvor mnogih perspektiva koje gravitiraju oko ideje realizma u posleratnom periodu i koje predstavljaju značajan momenat u teorijskoj raspravi i projektantskoj praksi između tridesetih i pedestih, sve do Staljinove smrti.

Cilj ovog članka je da predloži jedno artikulisano razmišljanje o iskustvu socrealizma, istraženog u njegovim "formativnim" godinama, u ključnoj fazi njegove razrade. Daleko od toga da je rezultat krutog, teoretskog određenja od vrha nadole, realizam je definisan na pragmatičan način, u većini radova projektanske prakse i teorije. Eklekticizam i pluralizam njegovih izražaja, koji gravitiraju oko ideje kritičke asimilacije istorije, objašnjava razvoj socrealizma između ratnog i posleratnog perioda u SSSR i istočno evropskim zemljama i nalazi svoj najjasniji iskaz u moskovskom metrou. 


\section{MANFREDO TAFURI I KRITIKA REALIZMA}

\section{Luka Skansi}

Jedna od glavnih tema istorijskog rada Manfreda Tafurija, bilo da je analizirao arhitekturu renesanse, iluminizma ili dvadesetog veka, ticala se odnosa između arhitektonskog stvaralaštva i stvarnosti. Ova tema takođe je premisa, odnosno uvodni teorijski okvir, za njegov istorijski i kritički diskurs "kritike realizma", koji je opisan u eseju Architettura e Realismo (Arhitektura i realizam), objavljenom 1985. godine. Ovaj esej predstavlja zaključne Tafurijeve opservacije italijanske posleratne arhitektonske kulture. Neorealizam postaje u njegovom eseju predmet prilično jedinstvene istorijske kontekstualizacije, predmet duboke kritike i, konačno, demistifikacije.

KLJUČNE REČI: ARHITEKTURA, REALIZAM, NEOREALIZAM, KRITIKA, POSLERATNA ITALIJA

\section{FRENK LOJD RAJT, EJN REND I HIPER-KAPITALISTIČKA UTOPIJA}

\section{Tijana Vujošević}

Ovaj rad predstavlja paralelno čitanje Frenk Lojd Rajtovog traktata Iščezavajući grad i Ejn Rendovog romana The Fountainhead. Autorka istražuje retoriku anti-urbanih utopija iz ere Depresije isnspirisanu mitom američkih pionira i osvajanjem granice. Ona identifikuje tri karakteristike Rajtovih i Rendovih anti-urbanih konstrukta: slavljenje muževnosti, poricanje političkog angažmana i anti-intelektualizam, sve to kombinovano u snu prvobitnog, idealnog kapitalizma. Koje su protivrečnosti i nedoslednosti svojstvene u građenju anti-urbane utopije? Ovo je pitanje na koje ovaj rad namerava da odgovori.

KLJUČNE REČI: MODERNIZAM, UTOPIJSKA FIKCIJA, ANTI-URBANIZAM, USONIA, THE FOUNTAINHEAD -

FAUNTEJNHED, IDEOLOGIJA, MUŠKOST, ANTI-INTELEKTUALIZAM

\section{MESTO [PROSTOR] NE-MESTO \\ Krunoslav Ivanišin}

Čak iako se nikada ne materijalizuju kao zgrade, arhitektonski projekti pripadaju stvarnom svetu. Odvojeno od stvarnog prisustva, ali bez lišavanja merljivih prostornih osobina, ovi skupovi tehničkih crteža u srazmeri, opisa i proračuna objašnjavaju buduću fizičku relanost u pogledu prostora, materijalnosti i forme, sa ciljem stvaranja sveta bar malo boljeg nego što je onaj iz koga potiču. Topografski izazovno, divno mesto pored mora; neko specifično gusto urbano okruženje; intrigantan način razmišljanja : neposredni kontekst prethodi i prati stvarnu izgradnju arhitektonskog dela. To je očigledna činjenica sama po sebi koju istoricističke konceptualizacije i klasifikacije ne mogu da poreknu. UTOPIJSKI ili REALISTIČNI, arhitektonski projekti su po svojoj prirodi vezani za mesta. Samo mera njihovog mešanja i uplitanja sa tim mestima može da varira. U našem post-globalizovanom svetu, i utopijski i realistični kvaliteti se mogu naći u projektima koji su hiperrealistični prema neposrednom kontekstu i koji se kontekstima bave minimalno, samo u pogledu raspoređivanja opterećenja, prilagođavanja stvarnoj topografiji, ili klimatskoj zaštiti.

KLJUČNE REČI: MESTO, ARHITEKTA, PROJEKAT, MATERIJAL, [PROSTOR], KONTEKTS, ARHITEKTURA, NE- MESTO 